\title{
Cost Benefit Analysis of Victims, Offenders, Child Communities In The Criminal Justice System
}

\author{
Ani Purwati ${ }^{2}$, Farina Gandryani ${ }^{2}$ \\ \{anipurwati@uwp.ac.id ${ }^{1}$, farinagandryani@uwp.ac.id $\left.{ }^{2}\right\}$
}

Wijaya putra university, Jl. Raya Benowo 1-3 Surabaya

\begin{abstract}
The effectiveness of prevention and prevention of child crime at the level of investigation, prosecution, and court consider the proportional value of justice restorative justice through aspects of crimininology, penology and integrated victimology to the accountability of criminal acts of economic approaches to external costs and social costs of both perpetrators, victims and society. The focus of the problem has not been the maximum proportional calculation of the programs and costs of loss of the juvenile justice system in Indonesia. The purpose of this study is to know the settlement of child cases dealing with laws that are equita-ble restorative justice through diversion considering the principle of cost benefit analysis. Normative juridical research method with conceptual approach and legal comparison. Research results of Actors, Victims and Communities benefited from cost benefit analysis of handled crime and increased community satisfaction in the juvenile justice system in Indonesia.
\end{abstract}

Keywords: Justice Restorative Justice, Diversion, Cost Benefit Analysis.

\section{Introduction}

The problem of the implementation of diversion in the criminal justice system in Indonesia in the first place is not yet maximizing the child welfare goals towards the settlement of criminal cases as ultimum remedium the decision to impose criminal sanctions and the verdict of diversion of children returned by parents [1], [2]. Second, the limited facilities and infrastructure during the judicial process (pre and post court decisions) and the minimum number of special guidance institutions for children in each province so that they have not been fully separated. Third, the real conditions in the field of diversion data are not integrat-ed at the police and correctional center level. Fourth, there is no nomen-clature that regulates the temporary, fifth child placement institution, coordination between law enforcement officers (police, prosecutors' office, supreme court, ministry of law and human rights, ministry of social affairs, the ministry of women's and children's empowerment, the ministry of education, and the ministry of health are still partial, sectoral in implementing their policies and authorities.

Settlement of child crimes considers the value of proposinonality aspects of criminology, penology, and victimology. Consideration of diversion contains substantially, procedurally, culturally, it can measure the accountability and responsibility of actors during the deliberative process horizontally and the integrity of the commitment of court ac-countability as adjudication of the responsibilities of democratic countries [3], [4]. Crime prevention and effectiveness of diversion at the level of investigations, prosecutors and judges have operational standards procedures for assessing criminal actions and imposing sanctions are calcu-lated by cost benefit 
analysis regulated by the Tokyo Rules regulating the disposition of punishment by considering the rehabilitation of viola-tors, the interests of victims regarding economic sanctions and penalties monetary matters such as fines and compensation to victims in the ju-venile justice system in Indonesia [5]-[8].

Measurement of the accountability and passive and active responsibility of actors, victims and the public both prevention and rehabilitation programs [2], [9], [10], First, shifting the balance of veto rights of Law En-forcement and State Officials to collective supervision of the injustices of perpetrators and victims of the determination of non-participatory responsibilities in the process diversion, the two states took over re-sponsibility in every stage of the diversion of the police, attorney gen-eral's office, courts, correctional institutions to private organizations and state-owned enterprises to make repairs due to criminal acts. Third, the role of the mediator assesses satisfaction with mediated outcomes, im-proves recovery of perpetrators, victim consultation services and community recovery programs from the behavioral and cultural aspects of the community.

Minimum rules for administration of juvenile justice provide the au-thority of law enforcement authorities to take policy actions to deal with or resolve the problem of child offenders by not taking the formal process of judicial proceedings or giving back to the community and other forms of social service activities and emphasizing the proportion-ality of children's reactions those in conflict with the law are based on consideration of the severity of the violation of the law but also the consideration of personal circumstances (social status, family circum-stances, losses caused by other factors) that affect the child's personali-ty.

The concept of cost benefit analysis, is the thought of analyzing the legal economy of utilitarianism Jeremy Bentham emphasizes the princi-ple of expediency. Jeremy Bentham formulated the theory of preven-tion of the value of punishment not all cases were adjusted for the weight of the crime and the cost of the loss, but adjusted for the right punishment. Diversion can be measured through the theory of felicif calculus which predicts the level of community satisfaction due to the enactment of legal provisions that lead to improvement or misery. The economic tools approach does not eliminate the basic elements of value (utility), and efficiency (effencieny) as intended crime prevention in-puts (ius constituendum). Cost analysis and the benefits of tackling crime, according to Martin and Bradley, analysis of state costs calcu-lates losses for various types of crimes, comparing the dangers of crimes with other social crimes. to measure the cost of benefits in criminal jus-tice through the calculation of budget monitoring of the amount of crime prevention funding against the costs of handling police cases to the courts, imprisonment prevention programs. Whereas Richard A. Posner First, analyzes by optimizing between certainty and severity of penalties, namely the comparative economic nature of fines and prison sentences. Second, economic analysis of law enforcement and criminal procedural law has the effect of deterrent and the effect of preventing criminal law. Posner interprets legislation in the legislature and the court with several propositions.

There are 2 (two) cost analysis policies in crime prevention according to Becker, the calculation of external costs (The cost of violating the law and being responsible for the objects of crime) and social costs (The cost of substituting victims and society for losses suffered in non-material recovery efforts such as trauma, stigma community from the community) [5]-[7], [9], [11], [12]. The emphasis of diversion on legal economic principles is calculated through programs and budgets through consideration of the principles of equilibrium composation (the gap in rationality definitions, interest's perceptions and goals of child protection), gap-filing principle emphasizes the role of law enforcement officers and legal users in im-plementing hypothetical legal provisions. Bargains (monetary and non-monetary benefits, improvement of actors, victims and the public), cor-related productive principles (productivity level of legal 
arrangements through increased legal awareness of the public regarding legal sanc-tions against any legal irregularities).

The parameter of the 4 (four) Penalty to justify and determine ex ante and ex post excriminal punishment is not de facto committing a crime, but has an intention and even an attempt to commit a criminal act. Categorizing ex ante acts of crime fulfills the qualification requirements for being convicted. On the contrary, the ex post emphasizes punishment to people who are de facto committing crimes so as to ful-fill the requirements for criminal offenders. Both have different incen-tives to improve behavior and create legal order. Act-based rules or harm based rules (optimal punishment based on victim loss, reducing the probability of criminal offenses, calculating the deterrence form of criminal penalties that emphasizes the heaviest penalties imposed on types of criminal offenses that are lighter and have the option of committing several types of criminal acts, closed principle the range of as-sessment of the inability to guarantee peace and tranquility of all parties is the basis of punishment, while the open range is opportunistic as a result of its actions.

The principle of Disulity paying attention to the evaluation of convicted torturers during prison is greater than the maximum or mini-mum prison prison proportions. (Enforcement cost) On the other hand proportional is greater than disulity, so maximum prison sentence imprisonment is not optimal because it is unable to provide deterrence. The estimated cost and function of crime costs can calculate the costs of each crime in the community. First, understanding the crime of the phenomenon and the proportion comparing other social problems.

Second, assessing crime costs determines the priority of the government in dealing with crime. All resources that work against crime from legis-lative authorities working on decriminalization, determining the type and number of crimes, determine general policies to combat crime and budget allocations to justice, crime prevention. Development of MultiSystemic therapy programs for crime prevention programs through cost benefits, reduction in costs of monitoring and evaluating long-term costs, benefits of programs and policies to undertake alternative pro-grams to reduce crime, evaluated the cost of expenditure budget alloca-tion during the judicial process such as prisons and facilities detention, a comparison of the budget for the middle and lower classes.

Efficiency of diversion settlement is applied in Indonesia with the calculation and conditional discharge program, demands for criminal offenses are revoked if the suspect obeys certain requirements such as payment of a certain amount, provides social services to the community, or provides compensation to the victim, Simplification procedures sim-plified procedures speed up the process defendants in a better way, faster procedures such as offering demands or punishments, decriminal-izing (decriminalization) certain crimes, then being removed from the arena (jurisdiction) of criminal justice. Integration of the construction of facilities and infrastructure for perpetrators, victims according to opera-tional standards procedures for ideal conditions for child development institutions, and temporary child placement institutions totaling 18 units from 33 provinces in Indonesia, construction of social welfare institu-tions as welfare workers for 8 (eight) children at the provincial level. 4 (four) under the authority of the social ministry, and 4 (four) under the authority of the regional government.

Analysis of the budgetary costs of prevention and control of diver-sion programs calculated by interventions reduces recidivism and facili-tates potential crime programs by using the benefit cost classification method. There are 2 (two) intangible and intangible costs for reducing budget costs, as well as the effectiveness of child crime prevention and prevention programs, comparison financing of handling middle class law. The integration of the Central Government 
and Regional Govern-ment budgets by Law Enforcement Officials (APH) during the judicial process is the Minister of Empowerment Regulation of the Minister of Women Empowerment and Child Protection No. 1. 2010 concerning Minimum Service Standards for Integrated Services for Women and Children and the Financing Process in Handling Child Cases with Legal Aid in accordance with Minister of Law and Human Rights Decree No. M.HH-03. HN.03.03 of 2013 concerning the Amount of Litigation As-sistance and Non Litigation Costs for handling child cases.

The implementation of cost benefit analysis of diversion is carried out by means of criminal and civil settlement as well as the State of Australia regulated by the state of South Australia Section 6 Police cau-tion Young Offenders (diversion mechanism with apologies for perpetrators of victims), Section 8.1: Minor violations, Section 8 (1) : Formal caution: - payment of compensation or compensation for victims; ser-vice to the community (no more than 75 hours); as well as an apology to the victim, Western Australia Section 22: Ingat (caution), Sec. 7.g: Minor breach of Sec. 22 (3), schedules 1 and 2, Section 22: paying com-pensation to victims of violations, Tasmania Youth Justice Act 1997), Section 8: Informal warnings: children recognize violations, not record-ed in police, Section 8: Minor violations, Section 10 : give compensa-tion to victims; restitution; service to victims (no more than 35 hours); apologize to the victim.

Whereas the adoption of diversion of the State of China enacting the Victim Offender Reconciliation program formed by the people's mediation commission (PMC) adopted by the Government Council provided by the PMC was to mediate general civil cases and cases of minor criminal offenses (Article 3). PMC has the competence to handle minor criminal cases that occur in these environments. On the contrary, the current regulation states that PMC can only relate to civil disputes through mediation (Article 5). The VOR stage has 7 (seven) stages: (1) submitting a request to the VOR and its receipt; (2) preparation; (3) statement; (4) consultation and dialogue; (5) agreement; (6) inspection; and (7) performance. The prosecutor's committee can then make a decision not to try the suspect, provided that the criminal suspect acknowledges or feels guilty, and the victim: (a) Submits negotiations to agree to compensation, and (b) asks the prosecutor not to continue the prosecution. Besides the victim and the defendant must sign a written doc-ument, and the suspect must have sent compensation fees to the prosecutor's office.

\section{Conclusion}

The basic philosophy of regulating diversion in handling child legal conflicts as an alternative last resort and in accordance with the objec-tives of child criminal justice requires a philosophical study of the foundation of international and national legal instruments that contain the principle of proportional punishment and the best interest of the child. The principle of cost benefit analysis is the basis for the effec-tiveness of consideration of diversion in the juvenile justice system as an effort to overcome and prevent child crime through means of reason-ing, with legal and economic considerations to achieve satisfaction of the juvenile justice system in Indonesia.

\section{References}

[1] D. J. Levinson, “Collective Sanctions,” SSRN Electron. J., 2005. 
[2] K. Beckett and A. Harris, "On cash and conviction," Criminol. Public Policy, 2011.

[3] P. O. Kaplan, S. R. Ranjithan, and M. A. Barlaz, "Use of life-cycle analysis to support solid waste management planning for Delaware," Environ. Sci. Technol., 2009.

[4] K. M. Keyes, M. Cerdá, J. E. Brady, J. R. Havens, and S. Galea, "Understanding the rural-urban differences in nonmedical prescription opioid use and abuse in the United States," Am. J. Public Health, 2014.

[5] P. T. Minh, B. T. Tuyet, T. T. T. Thao, and L. T. T. Hang, "Application of ensemble Kalman filter in WRF model to forecast rainfall on monsoon onset period in South Vietnam," VIETNAM J. EARTH Sci., 2018.

[6] F. Walsh, "Family resilience: A framework for clinical practice," Fam. Process, 2003.

[7] D. Heemskerk, M. Caws, B. Marais, and J. Farrar, "Prevention," in SpringerBriefs in Public Health, 2015.

[8] R. V. Clarke, "Situational crime prevention," in Environmental Criminology and Crime Analysis: Second Edition, 2016.

[9] T. M. Best, “A Comparison of 2 Rehabilitation Programs," J. Orthop. Sports Phys. Ther., 2003.

[10] F. De Blasio, F. De Blasio, and E. Clini, "Pulmonary rehabilitation," in Exercise and Sports Pulmonology: Pathophysiological Adaptations and Rehabilitation, 2019.

[11] Singapore National Crime Prevention Council, "Crime Prevention through Environmental Design; Guide Book,” Prevention, 2003.

[12] N. Tilley, Crime prevention. 2014. 